Bioorganic \& Medicinal Chemistry Reports

\title{
The synthesis of two novel bicyclic haloketones and measurement of their biological activity
}

\author{
Esen Yıldız Bekfelavi ${ }^{1}$, Pınar Küce Çevik $\odot^{2}$, Özgür Yılmaz ${ }^{1}$, \\ Nermin Şimşek Kuş ${ }^{1 *}$, Gökhan Coral $\odot^{3}$ and Ayla Çelik $\odot^{2}$ \\ ${ }^{1}$ Department of Chemistry, Faculty of Arts and Sciences, Mersin University, 33343, Mersin, Türkiye \\ ${ }^{2}$ Department of Biology, Faculty of Arts and Sciences, Mersin University, 33343, Mersin, Türkiye \\ ${ }^{3}$ Department of Biotechnology, Faculty of Arts and Sciences, Mersin University, 33343, Mersin, Türkiye
}

(Received November 02, 2018; Revised December 28, 2018; Accepted December 31, 2018)

\begin{abstract}
The electrophilic addition of bromine to bicyclo[4.2.0]oct-3-en-7-one in $\mathrm{CHCl}_{3}$ at $0{ }^{\circ} \mathrm{C}$ led to $60 \%$ yield of trans- and $30 \%$ yield of cis-dibromide. The structure of the synthesized molecules was determined using ${ }^{1} \mathrm{H}$ and ${ }^{13} \mathrm{C}$ NMR spectra. The biological activity of cis- and trans-dibromide was investigated in terms of antibiotic and toxic effects at cellular level using microbiologic and cytogenetic test, respectively. The antimicrobial activity of transdibromide9 and cis-dibromide10 was tested against Bacillus spizizenii ATCC 6633, Salmonella typhimurium ATCC 14028,Staphylococcus aureus ATCC 25923, Escherichia coli ATCC 25922 and Pseudomonas aeruginosa ATCC 9027. Peripheral blood lymphocytes culture assay was used for determining the cytotoxicity of trans-dibromide 9 and cis-dibromide 10 substrates. Cis- and trans-dibromide showed antibiotic activity and the toxic effects of cis-and transdibromide were measured at cellular level by mitotic index as the cell kinetic parameter in a peripheral lymphocyte culture assay.
\end{abstract}

Keywords: Dibromoketone; biological activity; antibiotic effect; toxic effect; mitotic index. (C) 2018 ACG Publications. All rights reserved.

\section{Introduction}

Research related to the synthesis of bioactive natural products (Scheme 1) has attracted interest since the discovery of antibiotic activity by Fleming in $1929 .{ }^{1}$ A large number of studies followed that discovery on the synthesis and activity of antibiotics. ${ }^{2-7}$ In 2008 , Zareef et al. synthesized some derivatives of acylhydrazine including benzene diazasulfonamides and newly synthesized molecules were screened in vitro for their antibacterial activity and some for their antifungal activity. ${ }^{8}$ Balemans et al. identified new diarylquinoline drug candidates (3) with inhibitory activity against gram-positive pathogens and rapid bactericidal activity on S.aureus in 2012. ${ }^{9}$ Organohalogen molecules frequently display the highest level of biological activity. Recently, we described the synthesis and biological activity of epoxide $\mathbf{4}$ containing a bicyclic skeletal structure in terms of antibiotic and toxic effects at cellular level. ${ }^{10}$ Another recent study concerned the synthesis of potent macrolide antibiotics $\mathbf{5}$ with in situ click chemistry in which 70S E. coli

\footnotetext{
* Corresponding author: E-mail: simner@mersin.edu.tr Tel: +903243610001/14558 Fax: +903243610046
} 
ribosomes and 50S ribosomal subunits were employed as platforms by Glassford et al. ${ }^{11} \mathrm{MI}$ is commonly used as the cell kinetic parameter in many studies. ${ }^{12-18}$ It is considered as a parameter used in the measurement of biologic activities of the substances synthesized in many chemical synthesis studies. ${ }^{10,19}$

In this study, we aimed to synthesize the brominated molecules and investigate the activity of the synthesized molecules.
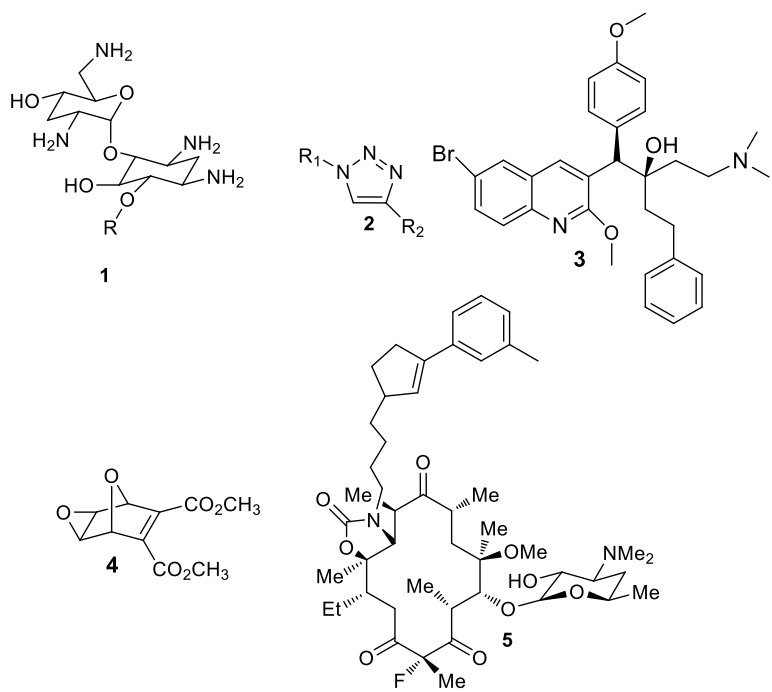

Scheme 1. Some of the biologically active molecules

\section{Experimental}

\subsection{Materials and apparatus}

RPMI 1640, Fetal Calf serum and phytohemagglutinin were purchased from Gibco. Mitomycin C was used as positive control for lymphocytes assay and purchased from Sigma. Other chemicals or solvents used in this study were of cell culture, HPLC, or analytical grade. Melting points were determined with a Mettler Toledo MP90 melting point system and were not corrected. Infrared spectra was recorded on a Perkin Elmer Win First ${ }^{\circledR}$ Satellite. The ${ }^{1} \mathrm{H}$ and ${ }^{13} \mathrm{C}$ NMR spectra were recorded on a Bruker Ultrashield Plus Biospin $\mathrm{GmbH} 400 \mathrm{MHz}$ spectrometer. Column chromatography was performed on silica gel (Kiesel 60, 230-400 mesh, Merck). TLC was carried out on Merck $0.2 \mathrm{~mm}$ silica gel $60 \mathrm{~F}_{254}$ analytical aluminum plates. All substances reported in this paper were in racemic form.

\subsection{Chemistry}

2.2.1. Ketene Addition Reaction of 1,4-cyclohexadiene (6): To a magnetically stirred solution of 1,4cyclohexadien $(6)(62.5 \mathrm{mmol}, 5 \mathrm{~g})$ in anhydrous diethyl ether $(250 \mathrm{~mL})$ at room temperature in a 1-L threenecked flask equipped with a condenser, addition funnel, and nitrogen atmosphere was added $\mathrm{Zn}-\mathrm{Cu}(125$ mmol, $8.15 \mathrm{~g}$ ). The suspension was stirred under $\mathrm{N}_{2}$ and with a solution of trichloroacetyl chloride (62.5 mmol, $11.35 \mathrm{~g})$ and phosphoryl trichloride $(62.5 \mathrm{mmol}, 9.58 \mathrm{~g})$ in diethyl ether $(50 \mathrm{~mL})$. The mixture was stirred for $24 \mathrm{~h}$ at room temperature. After the mixture was filtered on Celite, the ethereal solution was washed with saturated $\mathrm{NaHCO}_{3}$ and dried with $\mathrm{MgSO}_{4}{ }^{20}$ Chromatography of the residue on $50 \mathrm{~g}$ of silica gel eluting with diethyl ether/hexane (3:7) afforded dichlorobicyclic ketone $7(87 \%, 54.4 \mathrm{mmol}, 10.4 \mathrm{~g})$ as a colorless liquid.

8,8-dichlorobicyclo[4.2.0]oct-3-en-7-one (7): Yield 87\%. Colorless liquid, IR ( $\left.\mathrm{cm}^{-1}\right)$ 2983, 1804, 1735, $1445,1372,1237,1044,{ }^{1} \mathrm{H}\left(400 \mathrm{MHz}, \mathrm{CDCl}_{3}\right): \delta 5.8(\mathrm{~m}, 2 \mathrm{H}), 3.98(\mathrm{ddd}, J=10.6,6.8,2.4 \mathrm{~Hz}, 1 \mathrm{H}), 3.2$ ppm (ddd, $J=8 \mathrm{~Hz}, 2 \mathrm{~Hz}, 1 \mathrm{H}), 2.6-2(\mathrm{~m}, 4 \mathrm{H}),{ }^{13} \mathrm{C}\left(100 \mathrm{MHz}, \mathrm{CDCl}_{3}\right)$ : 198.3, 127.3, 126.4, 53.7, 45.2, 23.1, 21.3. 
2.2.2. Reduction of 8,8-dichlorobicyclo[4.2.0]oct-3-en-7-one(7): To a vigorously stirring suspension of $\mathrm{Zn}$ $(168.4 \mathrm{mmol}, 11 \mathrm{~g})$ in $150 \mathrm{~mL}$ of glacial acetic acid at room temperature, was added dropwise a solution of dichlorobicyclic ketone $7(42.11 \mathrm{mmol}, 8 \mathrm{~g})$ in $50 \mathrm{~mL}$ of acetic acid. After addition was complete, the temperature was raised to and maintained at $100{ }^{\circ} \mathrm{C}$ for $20 \mathrm{~h}$. The reaction mixture was cooled and treated with diethyl ether, and the zinc residue was filtered. The ethereal layer was washed with water and a saturated solution of sodium bicarbonate to remove acetic acid and then it was dried with $\mathrm{MgSO}_{4}$. The solvent was removed in an evaporator. Chromatography of the residue on $50 \mathrm{~g}$ of silica gel eluting with diethyl ether/hexane (1:1) afforded bicyclic ketone $\mathbf{8}(95 \%, 40 \mathrm{~mol}, 4.88 \mathrm{~g})$ as a pale yellow viscous oil. ${ }^{20}$

Bicyclo[4.2.0]oct-3-en-7-one (8): Yield 95\%. Pale yellow viscous oil; IR ( $\left.\mathrm{cm}^{-1}\right)$ 2950, 1788, 1654, 1420, 1248, 1166. ${ }^{1} \mathrm{H}$ NMR $\left(\mathrm{CDCl}_{3}, 400 \mathrm{MHz}\right): \delta 5.8\left(\mathrm{~m}, 2 \mathrm{H}, \mathrm{H}_{3}\right.$ and $\left.\mathrm{H}_{4}\right), 3.45\left(\mathrm{~m}, 1 \mathrm{H}, \mathrm{H}_{6}\right), 2.55\left(\mathrm{~m}, \mathrm{H}_{1}\right), 2.4-2.2$ $\left(\mathrm{m}, 4 \mathrm{H}, \mathrm{H}_{2}, \mathrm{H}_{5}\right),{ }^{13} \mathrm{C} \mathrm{NMR}\left(\mathrm{CDCl}_{3}, 100 \mathrm{MHz}\right): \delta 213.2,127.4,126.5,56.6,52.1,26.5,22.1,21.8$.

2.2.3. Bromination of bicyclo[4.2.0]oct-3-en-7-one (8): To a magnetically stirred solution of bicyclic ketone $8(32.8 \mathrm{mmol}, 4 \mathrm{~g})$ in $20 \mathrm{~mL}$ of dry chloroform cooled to $25^{\circ} \mathrm{C}$ was added dropwise a solution of bromine $\left(39.4 \mathrm{mmol}, 6.3 \mathrm{~g}\right.$ ) in $5 \mathrm{~mL}$ of chloroform for $10 \mathrm{~min}$. After stirring for 5 minutes at $25^{\circ} \mathrm{C}$, the solution was slowly warmed to room temperature. ${ }^{21}$ After removal of the solvent under reduced pressure, the oily residue was chromatographed over silica gel $(20 \mathrm{~g})$ with carbon tetrachloride as the eluent to giveof trans-dibromide $\mathbf{9}(60 \%, 18.4 \mathrm{mmol}, 5.18 \mathrm{~g})$ and cis-dibromide $\mathbf{1 0}(30 \%, 12.8 \mathrm{mmol}, 3.6 \mathrm{~g})$ as a pale yellow viscous oil.

trans-3,4-Dibromobicyclo[4.2.0]octan-7-one (9): Yield 60\%. Pale yellow viscous oil; IR $\left(\mathrm{cm}^{-1}\right) 2922$, $1779,1424,1359,1316,1248,1167,1089,1050,1007,970,{ }^{1} \mathrm{H}$ NMR $\left(\mathrm{CDCl}_{3}, 400 \mathrm{MHz}\right): \delta 4.54(1 \mathrm{H}, \mathrm{m}$, $\left.\mathrm{H}_{3}\right), 4.48\left(1 \mathrm{H}, \mathrm{m}, \mathrm{H}_{4}\right), 3.27\left(2 \mathrm{H}, \mathrm{m}, \mathrm{H}_{6}\right.$ and $\left.\mathrm{H}_{8 \mathrm{a}}\right), 2.73\left(1 \mathrm{H}, \mathrm{m}, \mathrm{H}_{1}\right), 2.62\left(1 \mathrm{H}, \mathrm{m}, \mathrm{H}_{8 \mathrm{~b}}\right), 1.35\left(3 \mathrm{H}, \mathrm{m}, \mathrm{H}_{5 \mathrm{a}}, \mathrm{H}_{5 \mathrm{~b}}\right.$ and $\left.\mathrm{H}_{2 \mathrm{~b}}\right), 2.35\left(1 \mathrm{H}\right.$, ddd, $\left.J=15.5,9.84,2.79 \mathrm{~Hz}, \mathrm{H}_{2 \mathrm{a}}\right),{ }^{13} \mathrm{C} \mathrm{NMR}\left(\mathrm{CDCl}_{3}, 100 \mathrm{MHz}\right): \delta 207.4(\mathrm{C}=\mathrm{O}), 52.99$ $(\mathrm{CH}), 51.9\left(\mathrm{CH}_{2}\right), 50.1(\mathrm{CH}), 48.3(\mathrm{CH}), 31.5\left(\mathrm{CH}_{2}\right), 26.2\left(\mathrm{CH}_{2}\right), 19.7(\mathrm{CH})$; GCMS m/z 239.9, $\left(\mathrm{M}^{+},-\mathrm{Br}\right)$, 159.0, ( $\left.\mathrm{M}^{+},-\mathrm{Br}\right)$, 79.1. Anal. Calcd. For $\mathrm{C}_{8} \mathrm{H}_{10} \mathrm{Br}_{2} \mathrm{O}$ : C, 34.08, H, 3.57\%. Found: C, 34.11, H, 3.59\%.

cis-3,4-Dibromobicyclo[4.2.0]octan-7-one (10): Yield 30\%.Pale yellow viscous oil; IR ( $\left.\mathrm{cm}^{-1}\right)$ 2931, 1774, $1435,1400,1338,1209,1170,1097,1067,1023,957 .{ }^{1} \mathrm{H}$ NMR $\left(\mathrm{CDCl}_{3}, 400 \mathrm{MHz}\right): \delta 4.22\left(2 \mathrm{H}, \mathrm{m}, \mathrm{H}_{3}\right.$ and $\left.\mathrm{H}_{4}\right), 3.41\left(1 \mathrm{H}, \mathrm{m}, \mathrm{H}_{6}\right), 3.16\left(1 \mathrm{H}, \mathrm{ddd}, J=16.7,8.8,3.1 \mathrm{~Hz}, \mathrm{H}_{8 \mathrm{a}}\right), 2.84\left(2 \mathrm{H}, \mathrm{m}, \mathrm{H}_{2 \mathrm{a}}\right.$ and $\left.\mathrm{H}_{8 \mathrm{~b}}\right), 2.69(1 \mathrm{H}, \mathrm{dt}$, $\left.J=15.1,3.7 \mathrm{~Hz}, \mathrm{H}_{5 \mathrm{a}}\right), 2.61\left(1 \mathrm{H}, \mathrm{m}, \mathrm{H}_{1}\right), 2.09\left(1 \mathrm{H}, \mathrm{dt}, J=15.1,8.8 \mathrm{~Hz}, \mathrm{H}_{5 \mathrm{~b}}\right), 1.84\left(1 \mathrm{H}, \mathrm{m}, \mathrm{H}_{2 \mathrm{~b}}\right),{ }^{13} \mathrm{C} \mathrm{NMR}$ $\left(\mathrm{CDCl}_{3}, 100 \mathrm{MHz}\right): \delta 206.4(\mathrm{C}=\mathrm{O}), 55.7(\mathrm{CH}), 52.4\left(\mathrm{CH}_{2}\right), 52.3(2 \mathrm{CH}), 37.5\left(\mathrm{CH}_{2}\right), 29.9\left(\mathrm{CH}_{2}\right), 22.5(\mathrm{CH})$. GCMS m/z, 239.9, ( $\left.\mathrm{M}^{+},-\mathrm{Br}\right), 159.0,\left(\mathrm{M}^{+}\right.$, -Br), Calcd. For $\mathrm{C}_{8} \mathrm{H}_{10} \mathrm{Br}_{2} \mathrm{O}$ : C, 34.08, H, 3.57\%. Found: C, 34.13, $\mathrm{H}, 3.55 \%$.

\subsection{Antimicrobial assay}

The antimicrobial activity of trans-dibromide $\mathbf{9}$ and cis-dibromide $\mathbf{1 0}$ was tested against Bacillus spizizenii ATCC 6633, Salmonella typhimurium ATCC 14028, Staphylococcus aureus ATCC 25923, Escherichia coli ATCC 25922 and Pseudomonas aeruginosa ATCC 9027.

2.3.1. Preparation of microbial cultures and for antimicrobial activity test of cis- and trans-3,4dibromobicyclo[4.2.0]octan-7-one

Disc diffusion method was performed according to the standard method by Bauer et al. to assess the presence of antibacterial activities of the test compounds [22]. The antimicrobial activity of transdibromide 9 and cis-dibromide 10 was tested against S. typhimurium ATCC 14028, P. aeruginosa ATCC 9027, B. spizizenii ATCC6633, E. coli ATCC 25922, and S. aureus ATCC 25923. The bacteria strains were incubated in LBbroth (Difco). Temperature conditions set to $37^{\circ} \mathrm{C}$ and incubation time was set to 24 hours. In accordance with the agar disc diffusion method, the bacteria were inoculated on Mueller-Hinton Agar (Merck). Test samples were dissolved using ethanol (96\%). $10 \mu \mathrm{L}$ was added to empty discs (6 mm) 
(Bioanalyse) from each test solution and incubated for 10 minute. After that, the discs were were placed on the surface of the agar and then incubated for 24 hours. Ethanol absorbed discs were used for solvent control. The inhibition zones on the plates were measured in mm using tobramycin (10 $\mu \mathrm{g})$ (Bioanalyse) as standard drug.

\subsubsection{Time-kill Assay}

The time-kill test was carried out using the macrodilution technique in accordance with the NCCLS standard and was performed in broth culture containing test substances which final concentration of $0,25 \mathrm{x}$ MIC, 1x MIC, 2xMIC, Tobramycin $(10 \mu \mathrm{g} / \mathrm{mL})$ and growth control. ${ }^{23} 30 \mathrm{ml}$ broths were inoculated to give a final inoculum of $105 \mathrm{cfu} / \mathrm{mL}$ which adjusted to $0,5 \mathrm{McFarland}$ turbidity standard and diluted $1 / 100$ with $0,85 \%$ sodium chlorid solution. Broths were incubated at $36^{\circ} \mathrm{C}$ with shaking and samples from broth were taken for varied time intervals $(0,2,4,6,8,10,12$ and $24 \mathrm{~h})$ and plated nutrient agar (Merck). Viable counts were read manually after $24 \mathrm{~h}$ incubation. All antimicrobial activity tests were conducted in triplicate.

\subsection{Eukaryotic system assay/Lymphocyte cultures in peripheral blood lymphocytes and mitotic index}

Peripheral blood lymphocytes culture assay was used for determining the cytotoxicity of transdibromide $\mathbf{9}$ and cis-dibromide $\mathbf{1 0}$ substrates. In vitro analysis was performed in human blood lymphocytes from three donors at four concentrations of each substrate $(150 \mu \mathrm{g} / \mathrm{mL}, 200 \mu \mathrm{g} / \mathrm{mL}, 250 \mu \mathrm{g} / \mathrm{mL}$ and 300 $\mu \mathrm{g} / \mathrm{mL}$ ). The cytotoxicity of the substrates were evaluated by using mitotic index (MI), the parameter of cytotoxicity in human peripheral blood lymphocyte cultures.

The study was performed using blood samples from three healthy non-smoking male donors, aged 26,24 and 25 years. In the three donors, the results of clinical routine laboratory analyses were within the normal ranges, and the absence of exposure to known genotoxicants was assumed. Lymphocyte cultures were prepared according to the technique described by Moorhead et al. with slight modifications. ${ }^{16}$ Heparinized whole blood ( $1 \mathrm{~mL}$ ) was added to $6 \mathrm{~mL}$ of RPMI 1640 medium (Gibco, USA), supplemented with $20 \%$ fetal calf serum (Gibco, USA), $0.1 \% \mathrm{~mL}$ phytohemagglutinin (Gibco,USA), and antibiotics $(10,000 \mu \mathrm{g} / \mathrm{mL}$ penicillin and $10,000 \mathrm{IU} / \mathrm{mL}$ streptomycin). Lymphocytes were cultured for $72 \mathrm{~h}$, and metaphases were blocked during the last $1.5 \mathrm{~h}$ with colcemid at a final concentration of $0.2 \mu \mathrm{g} / \mathrm{mL}$. Mitomycin C ( $2 \mu \mathrm{g} / \mathrm{mL})$ was used as positive control. The cells were harvested by replacing the culture medium with $\mathrm{KCl}(0.075 \mathrm{M})$ in which cells were incubated for $20 \mathrm{~min}$ at $37{ }^{\circ} \mathrm{C}$. The cells were fixed in Carnoy's fixative (methanol:acetic acid, 3:1 v:v) five times, and the slides were kept at room temperature overnight. The air-dried slides were stained with $5 \%$ Giemsa stain.

\subsubsection{Microscopic evaluation}

The MI was calculated as the proportion of metaphases among the total cell population by counting 1,000 cells for each dose treatment.

\subsubsection{Statistical evaluation}

The data were compared using one-way variance analysis. Statistical analysis was performed using SPSS for Windows 21.0 Post hoc analysis was performed using the least significant difference (LSD) test.

\section{Results and discussion}

Ketene cyclo addition reactions are reactions of diene of ketenes with unsaturated compounds to provide four-membered rings (Scheme 2) ${ }^{24,25}$ The addition of dichloroketene to 1,4-cyclohexadiene (6) was reported by Liotta et al., (1987), Davis et al., (1996) and Kishali et al., (2011). ${ }^{20,26,27}$ Bicyclic ketone 8 was obtained from elimination with $\mathrm{Zn}-\mathrm{Cu}$ in acetic acid. ${ }^{20,25}$ The ${ }^{1} \mathrm{H}$ and ${ }^{13} \mathrm{C}$ NMR spectra are in good agreement with addition product $\mathbf{7}$ and bicyclic ketone 8. Later, trans- and cis-dibromide $(\mathbf{9}, \mathbf{1 0})$ were obtained at $0{ }^{\circ} \mathrm{C}$ and $25{ }^{\circ} \mathrm{C}$ as a result of the bromination of bicyclic ketone $\mathbf{8}$ which were separated by 
column chromatography. ${ }^{21}$ Trans-Isomer $9(\mathrm{Rf}=0.95)$ has a larger $\mathrm{Rf}$ value than cis-isomer $10(\mathrm{Rf}=0.83)$ [hexane/ ethyl acetate mixture (9:1)]. trans-Dibromide 9 was formed as the major product with $60 \%$ yield. The absorption bands at $1779 \mathrm{~cm}^{-1}(\mathbf{9})$ and $1774 \mathrm{~cm}^{-1}(\mathbf{1 0})$ in the FT-IR spectra confirmed the cyclobutanone ring in the structure. In trans-dibromide $\mathbf{9}, \mathrm{H}_{4}$ and $\mathrm{H}_{6}$ are in trans position relative to each other. The chemical shifts of $\mathrm{H}_{5 \mathrm{a}}$ and $\mathrm{H}_{5 \mathrm{~b}}$ are close together (2.60 and $2.44 \mathrm{ppm}$ ). In cis-dibromide 10, bromine and oxygen shifted the chemical shift of $\mathrm{H}_{5 \mathrm{a}}$ in the downward direction in NMR. Therefore, the chemical shifts of $\mathrm{H}_{5 \mathrm{a}}$ and $\mathrm{H}_{5 \mathrm{~b}}$ are very far from each other (2.68 and $2.09 \mathrm{ppm}$ ). In molecule 9, bromine atom bound to $\mathrm{C}_{4}$ and cyclobutanone rings are in the same space since there is w-interaction; but bromine atom bound to $\mathrm{C}_{3}$ and cyclobutanone rings are in the different space since there is no w-interaction. In molecule $\mathbf{1 0}, \mathrm{C}_{3}$ and $\mathrm{C}_{4}$ protons did not give $\mathrm{w}$-interaction with $\mathrm{C}_{1}$ and $\mathrm{C}_{6}$ protons. This shows that the bromines are cis-position according to each other and in the trans-position with the cyclobutanone ring. It showed that cis-dibromide 10 occurred over radicalic mechanism in this reaction.

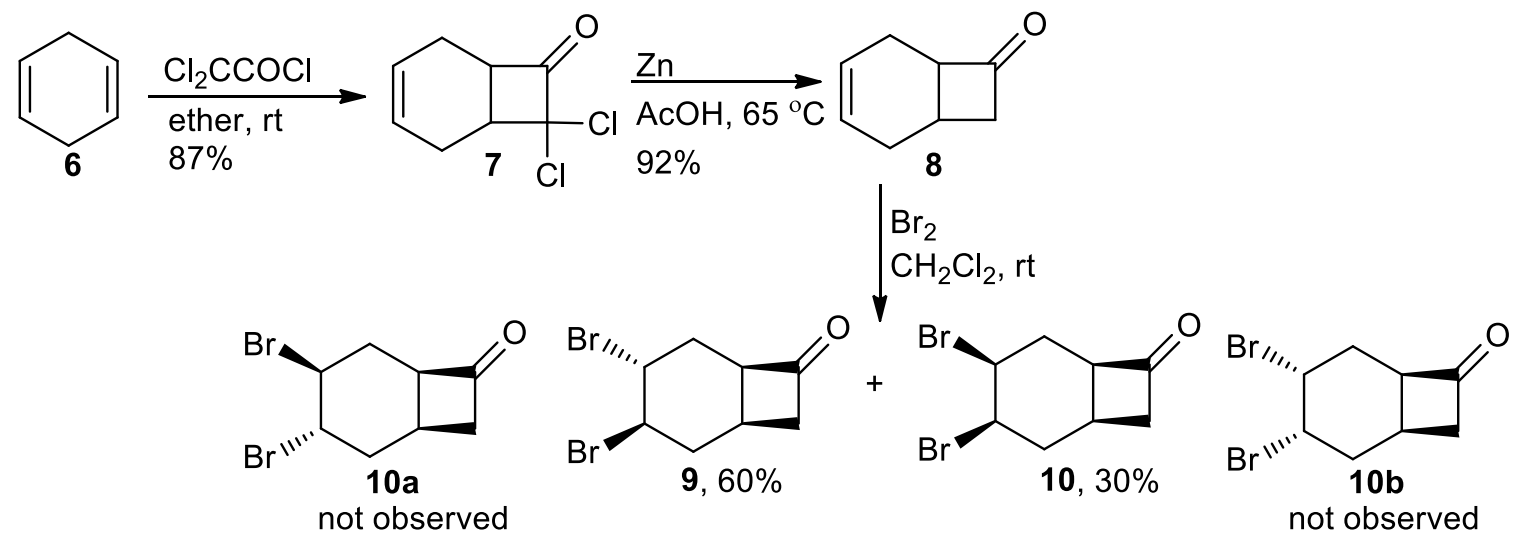

Scheme 2. Ketene addition to 1,4-cyclohexadiene (6) and the bromination reaction of bicyclic ketone $\mathbf{8}$

\subsection{The antimicrobial activity of trans- and cis-3,4-dibromobicyclo[4.2.0]octan-7-one (9 and 10)}

Inhibition zones were measured in mm compared with tobramycin $(10 \mu \mathrm{g})$ (Bioanalyse) as standard drug (Table 1 and 2). The Minimal inhibitory concentration (MIC) of the test solution of trans-dibromide 9 and cis-dibromide 10 were detected using Macrodilution test method. The tubes contained LB medium, ranging from 50 to $300 \mu \mathrm{g} / \mathrm{mL}$. The macrobroth dilutions were incubated for $24 \mathrm{~h}$ at $37{ }^{\circ} \mathrm{C}$ and spectrophotometrically measured (OD $600 \mathrm{~nm}$ ) to verify the presence or absence of growth (Fig.1 and 2). Only the Staphylococcus aureus strain was susceptible to the tested compound and MIC values of transdibromide $\mathbf{9}$ and cis-dibromide $\mathbf{1 0}$ for 150 and $200 \mu \mathrm{g} / \mathrm{mL}$ were obtained, respectively.

Table 1. Inhibitory effects of trans-dibromide 9 on the tested bacterial strains.

\begin{tabular}{|c|c|c|c|c|c|c|c|c|}
\hline \multirow[t]{2}{*}{ Bacteria } & \multicolumn{6}{|c|}{ Test $(\mathrm{mm}) \mathbf{9}$} & \multicolumn{2}{|l|}{ Controls } \\
\hline & $50 \mu \mathrm{g}$ & $100 \mu \mathrm{g}$ & $150 \mu \mathrm{g}$ & $200 \mu \mathrm{g}$ & $250 \mu \mathrm{g}$ & $300 \mu \mathrm{g}$ & Tobramycin $(10 \mu \mathrm{g})$ & Ethanol (96\%) \\
\hline S. aureus & - & 7.7 & 9.9 & 10.5 & 11.5 & 12.7 & 17.9 & - \\
\hline B.spizizenii & - & - & - & - & - & - & 23.1 & - \\
\hline E.coli & - & - & - & - & - & - & 11.05 & - \\
\hline P. aeruginosa & - & - & - & - & - & - & 25.85 & - \\
\hline S. typhimurium & - & - & - & - & - & - & 17.18 & - \\
\hline
\end{tabular}

Radii of the inhibition zones on the plates were measured in $\mathrm{mm}$. Tobramycin was used as standard drug for antibacterial activity 


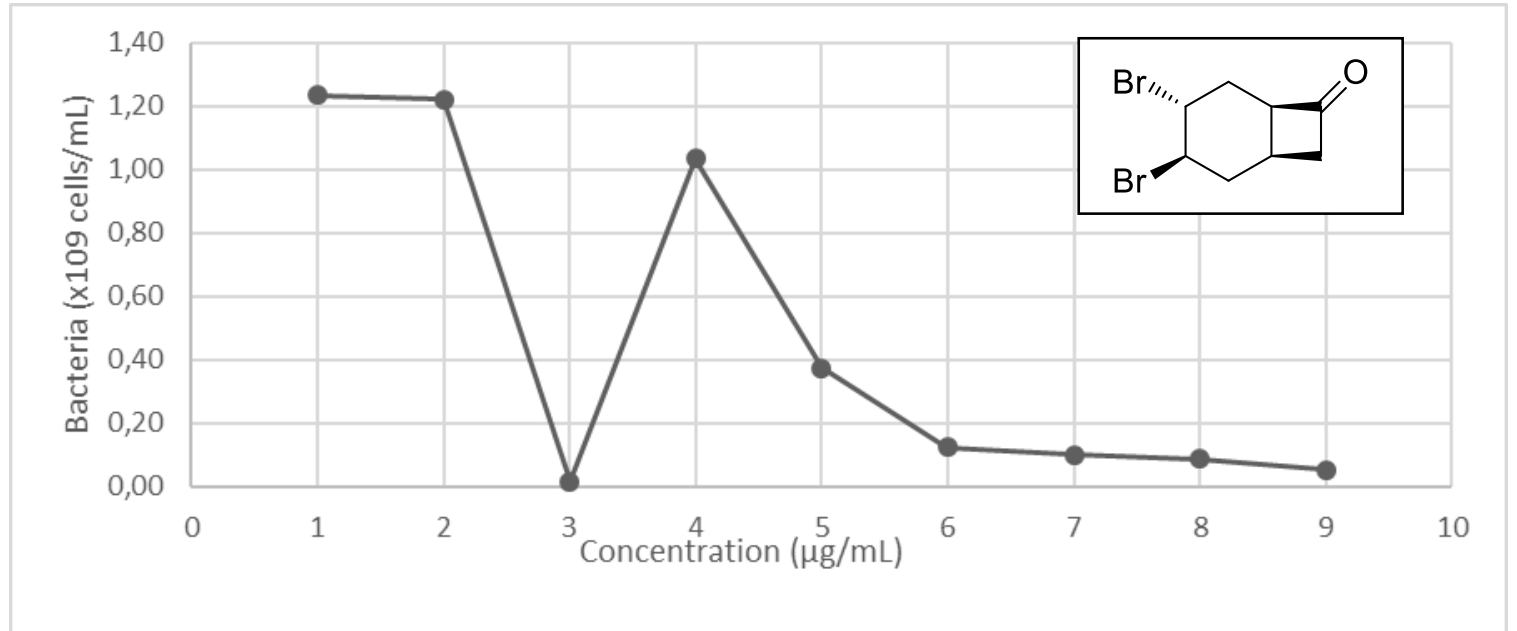

Figure 1. Effects of different concentrations of trans-dibromide 9 on the bacterial strain (S. aureus) tested.

Table 2. Inhibitory effects of cis-dibromide $\mathbf{1 0}$ on the tested bacterial strains.

\begin{tabular}{|c|c|c|c|c|c|c|c|c|}
\hline \multirow[t]{2}{*}{ Bacteria } & \multicolumn{6}{|c|}{ Test (mm) $\mathbf{1 0}$} & \multicolumn{2}{|l|}{ Controls } \\
\hline & $50 \mu \mathrm{g}$ & $100 \mu \mathrm{g}$ & $150 \mu \mathrm{g}$ & $200 \mu \mathrm{g}$ & $250 \mu \mathrm{g}$ & $300 \mu \mathrm{g}$ & Tobramycin $(10 \mu \mathrm{g})$ & Ethanol $(96 \%)$ \\
\hline S. aureus & 9.4 & 11.3 & 13.5 & 14.9 & 16.1 & 18.1 & 18.7 & - \\
\hline Bacillus spizizenii & - & - & - & - & - & - & 23.1 & - \\
\hline E.coli & - & - & - & - & - & - & 11.05 & - \\
\hline P. aeruginosa & - & - & - & - & - & - & 25.85 & - \\
\hline S. typhimurium & - & - & - & - & - & - & 17.18 & - \\
\hline
\end{tabular}

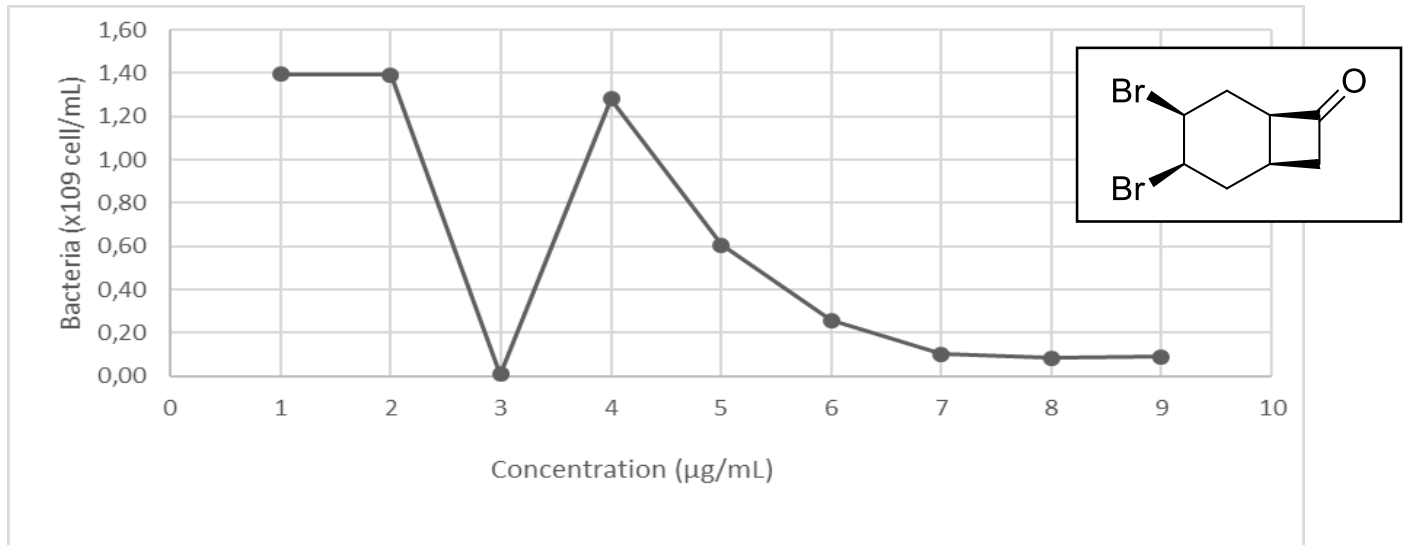

Figure 2. Effects of different concentrations of cis-dibromide $\mathbf{1 0}$ on the bacterial strain (S. aureus) q tested.

\subsection{Time-Kill Assay}

The time-kill curves of trans-dibromide 9 and cis-dibromide 10 against the $S$. aureus are shown in Figure 3 and 4 . A bactericidal effect was defined as $\mathrm{a} \geq 3 \log 10 \mathrm{cfu} / \mathrm{mL}$ decrease compared with the initial inoculum after $24 \mathrm{~h}$ of incubation. ${ }^{28}$ Trans-dibromide $\mathbf{9}$ and cis-dibromide $\mathbf{1 0}$ showed no bactericidal effect at a concentration of $0.25 \mathrm{xMIC}$. While concentration of $1 \mathrm{xMIC}$ trans-dibromide 9 reduced the amount of bacteria by less than $3 \log 10 \mathrm{CFU} / \mathrm{ml}-1,2 \mathrm{x}$ MIC concentration reduced the amount of bacteria by more than $3 \log 10 \mathrm{CFU} / \mathrm{ml}-1$ within 6 hours when compared to the growth control. Also, the concentration of 
2xMIC of cis-dibromide 10 substance caused a decrease in the amount of bacteria over $3 \log 10 \mathrm{CFU} / \mathrm{ml}-1$ within 6 hours. Nevertheless, 1xMIC concentrations of cis-dibromide $\mathbf{1 0}$ and trans-dibromide $\mathbf{9}$ showing bacteriostatic activity.

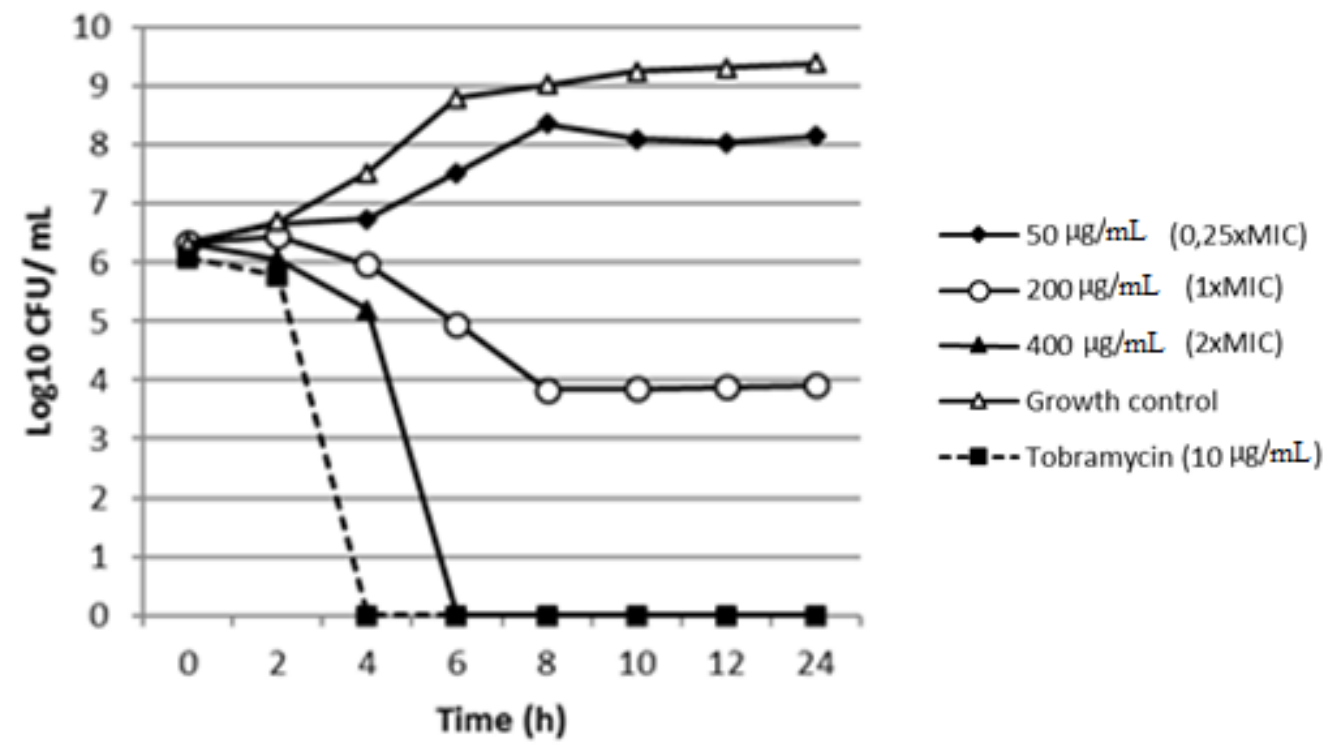

Figure 3. Time-Kill curve of trans-dibromide $9(\mu \mathrm{g} / \mathrm{mL}) *$

*Time-Kill curve of trans-dibromid $\mathbf{9}$ ( ug/ml)against $S$. aureus. $0,25 \times$ MIC (black diamonds); 1 xMIC (white circles); $2 \times$ MIC (black triangles); growth control (white triangles); and Tobramycin control (black square).

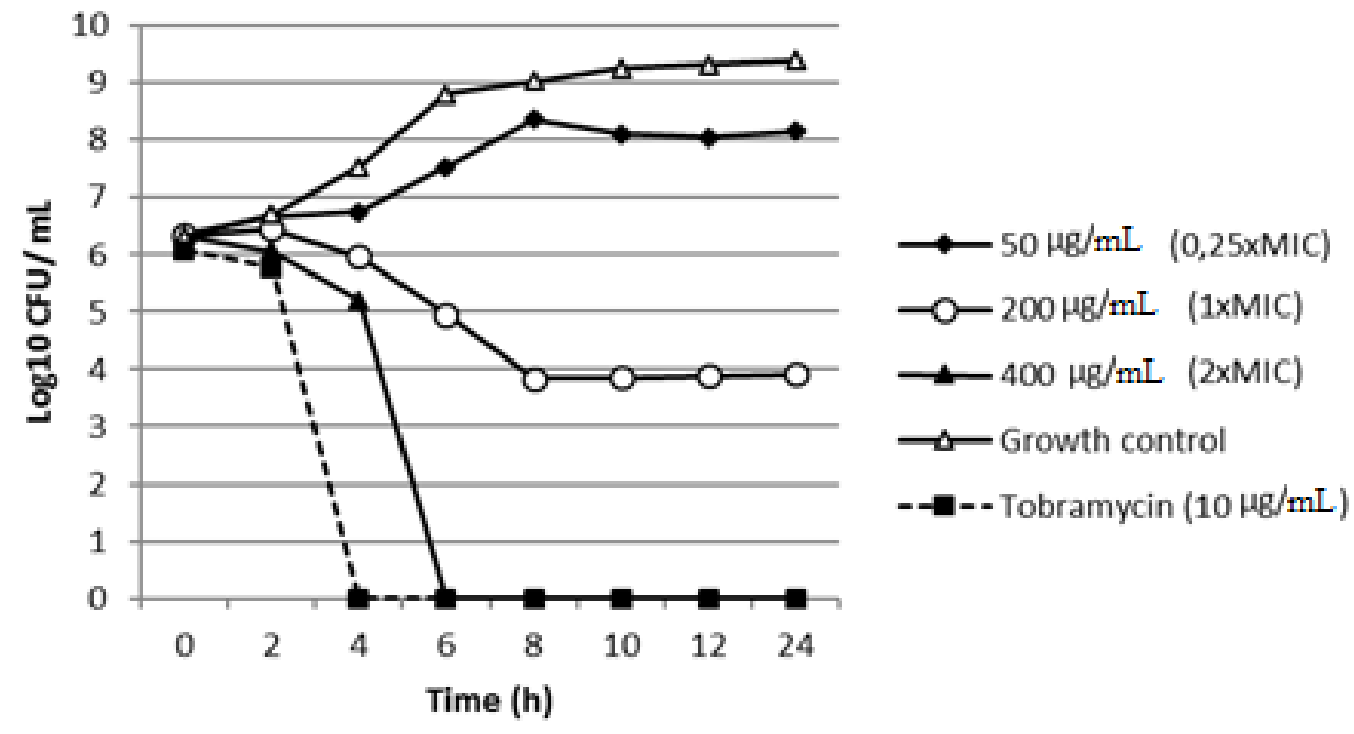

Figure 4. Time-kill curve of cis-dibromide $10(\mu \mathrm{g} / \mathrm{mL})^{*}$

*Time-Kill curve of cis-dibromid $\mathbf{1 0}$ ( ug/ml)against S. aureus. 0,25× MIC (black diamonds); 1xMIC (white circles); $2 \times \mathrm{MIC}$ (black triangles); growth control (white triangles); and Tobramycin control (black square)

\subsection{Cytotoxicity Results /Cell kinetic parameter-mitotic index (MI)}

Table 3 shows the values of MI in lymphocyte cultures treated with four different concentrations of trans-dibromide 9 and cis-dibromide 10 substrates $(150 \mu \mathrm{g} / \mathrm{mL}, 200 \mu \mathrm{g} / \mathrm{mL}, 250 \mu \mathrm{g} / \mathrm{mL}$ and $300 \mu \mathrm{g} / \mathrm{mL})$. 
All the concentrations of trans-dibromide 9 decreased the MI. There is a statistically significant difference between concentrations of trans-dibromide $9(150 \mu \mathrm{g} / \mathrm{mL}, 200 \mu \mathrm{g} / \mathrm{mL}, 250 \mu \mathrm{g} / \mathrm{mL}$ and $300 \mu \mathrm{g} / \mathrm{mL})$ and the negative control $(\mathrm{p}<0.05, \mathrm{p}<0.001)$. Two concentration $(150 \mu \mathrm{g} / \mathrm{mL}, 200 \mu \mathrm{g} / \mathrm{mL})$ of cis-dibromide 10 substrate increased the MI except for the concentration of $250 \mu \mathrm{g} / \mathrm{mL}$ of cis-dibromide 10. The concentration of $250 \mu \mathrm{g} / \mathrm{mL}$ of cis-dibromide $\mathbf{1 0}$ did not cause any change in mitotic index values. This increase is statistically significant $(\mathrm{p}<0.001)$. Moreover, $300 \mu \mathrm{g} / \mathrm{mL}$ concentrations of cis-dibromide10 substrate significantly decreased the MI $(\mathrm{p}<0.001)$.

Table 3. The values of MI in lymphocytes cultures treated with four different concentration of transdibromide $\mathbf{9}$ and cis-dibromide $\mathbf{1 0}$ in vitro.

\begin{tabular}{clllll}
\hline & \multicolumn{1}{c}{ Groups } & Donor 1 & Donor 2 & Donor 3 & Mean \pm SE \\
\hline 1 & $9-150 \mu \mathrm{g} / \mathrm{mL}$ & 47 & 62 & 59 & $56.8 \pm 4.58^{*}$ \\
2 & $9-200 \mu \mathrm{g} / \mathrm{mL}$ & 20 & 42 & 38 & $33.3 \pm 6.76^{* * *}$ \\
3 & $9-250 \mu \mathrm{g} / \mathrm{mL}$ & 12 & 20 & 16 & $16.0 \pm 2.30^{* * *}$ \\
4 & $9-300 \mu \mathrm{g} / \mathrm{mL}$ & 5 & 10 & 11 & $8.66 \pm 1.85^{* * *}$ \\
5 & $10-150 \mu \mathrm{g} / \mathrm{mL}$ & 96 & 108 & 102 & $102.0 \pm 3.46^{* * *}$ \\
6 & $10-200 \mu \mathrm{g} / \mathrm{mL}$ & 92 & 100 & 84 & $92.0 \pm 4.61^{* * *}$ \\
7 & $10-250 \mu \mathrm{g} / \mathrm{mL}$ & 67 & 65 & 79 & $70.3 \pm 4.37$ \\
8 & $10-300 \mu \mathrm{g} / \mathrm{mL}$ & 25 & 28 & 30 & $27.6 \pm 1.45^{* * *}$ \\
9 & $\mathrm{NC}$ & 66 & 67 & 71 & $68.0 \pm 1.52$ \\
10 & $\mathrm{PC}(\mathrm{MMC} 2 \mu \mathrm{g} / \mathrm{mL})$ & 34 & 41 & 33 & $36.0 \pm 2.51^{* * *}$ \\
$*$ & &
\end{tabular}

\section{Conclusion}

We synthesized dichlorobicyclic ketone 7 from 1,4-cyclohexadiene (6) in good yield by using a ketene addition reaction. After the reduction reaction of the chlorine, the addition of bromine to bicyclic ketone $\mathbf{8}$ was performed.

The in vitro antibacterial activity of the synthesized compounds were determined by broth macrodilution method using Gram-positive and Gram-negative organisms. Tobramycin used as a control antibiotic. It was observed that trans-dibromide $\mathbf{9}$ and cis-dibromide $\mathbf{1 0}$ showed antibiotic properties against S. aureus ATCC 25923. However, no antibacterial effects on the other test strains were observed. MIC values of trans-dibromide 9 and cis-dibromide 10 for 150 and $200 \mu \mathrm{g} / \mathrm{mL}$ were obtained, respectively.

Nowadays, people are exposed to various chemicals for many reasons such as environmental, occupational and therapeutic or lifestyle changes. Several chemicals have been shown to have toxic effects in many in vivo and in vitro studies including prokaryotic and eukaryotic systems. ${ }^{12-14,17,18,29}$ Several studies have indicated that one of the most major response in cells exposed to chemicals, ionizing radiation, and/or other genotoxic agents is the inhibition or the delay of cell-cycle progression. MI is used as an indicator of cell cytotoxicity. ${ }^{2,13,15}$

According to the data reported in the present study, four different concentrations of trans-dibromide $\mathbf{9}$ and cis-dibromide $\mathbf{1 0}$ affected the MI, considered as a parameter of cell kinetic or cytotoxic activity. The fact that all concentrations of trans-dibromide 9 cause a decrease in mitotic index values indicates that this substance can be considered as a mitotic inhibiting agent at the cellular level and in vitro. These data reveal that all the concentrations of trans-dibromide $\mathbf{9}$ had cytotoxic effects at cellular level and likewise, the 300 $\mu \mathrm{g} / \mathrm{ml}$ concentrations of cis-dibromide $\mathbf{1 0}$ has mitotic inhibitory properties because it cause a decrease in mitotic index values. It can be said that two concentrations $(150 \mu \mathrm{g} / \mathrm{mL}$ and $200 \mu \mathrm{g} / \mathrm{mL})$ of cis-dibromide 10 have a mitotic stimulating effect because this concentrations cause an increase in mitotic index values.

\section{Acknowledgements}

The authors are indebted to Mersin University [BAP-2015-AP4-1235, BAP-FBEKB (ÖY) 20141DR and BAP-2015-TP3-1236] for their financial support of this work. 
The synthesis of the novel bicyclic haloketones

\section{Supporting Information}

Supporting information accompanies this paper on http://www.acgpubs.org/journal/bioorganic-medicinal-chemistry-reports

\section{ORCID}

Esen Y1ld1z Bekfelavi: 0000-0002-3117-6784

Pınar Küce Çevik: 0000-0001-6722-6096

Özgür Y1lmaz: 0000-0001-9278-1091

Nermin Șimșek Kuș: 0000-0002-5402-2614

Gökhan Coral: 0000-0002-3533-118X

Ayla Çelik: $\underline{0000-0002-0127-3639}$

\section{References}

[1] Fleming, A. On the antibacterial action of cultures of a penicillium, with special reference to their use in the isolation of B. influenza. Br. J. Exp. Path. 1929, 10, 226-236.

[2] Bright, G.M.; Nagel, A.A.; Bordner, J.; Desai, K.A.; Dibrino, J.N.; Nowakowska, J.; Vincent, L.; Watrous, R.M.; Sciavolino, F.C.; English, A.R. Synthesis, in vitro and in vivo activity of novel 9-deoxo-9a-aza-9ahomoerrythromycin a derivatives: a new class of macrolide antibiotics, the azalides. J. Antibiot. 1988, 41(8), 1029-1047.

[3] Tolstikov, G.A.;. Shults, E.E.; Vafiva, G.F.; Tolstikova, T.G.; Davydova, V.A.; Ismagilova, A.F.; Spirikhin, L.V.; Zarudii, F.A.; Lazareva, D.N. Synthesis and biological activity of antibiotic analogs from the hydrogenated anthraquinone series. Pharmaceut. Chem. J., 1991, 11, 808-805.

[4] Wong, C.H.; Bryan, M.C.; Nyffeler, P.T.; Liu, H.; Chapman, E. Synthesis of carbohydrate-based antibiotics. Pure Appl. Chem. 2003, 75(2-3), 179-186.

[5] Sieber, S.A.; Marahiel, M.A Molecular mechanisms underlying nonribosomal peptide synthesis: approaches to new antibiotics. Chem. Rev. 2005, 105, 715-738.

[6] Aufort, M.; Herscovic, I.J.; Bouhours, P.; Moreau, N.; Girard, C. Synthesis and antibiotic activity of a small molecules library of 1,2,3-triazole derivatives. Bioorg. Med. Chem. Lett., 2008, 18(3), 1195-1198.

[7] Rowley, D.C. Total synthesis: A cascade of new antibiotics. Nat. Chem. 2009, 1, 110-112.

[8] Zaref, M.; Iqbad, R.; Mirza, B.; Khan, K.M.; Manan, A.; Asim, F.; Khan, S.W. Synthesis and antimicrobial activity of some derivatives of acylhydrazine including novel benznediazasulfonamides. Arkivoc, 2008, 141152.

[9] Balemans, W.; Vranckx, L.; Lounis, N.; Pop, O.; Guillemont, J.; Vergauwen, K.; Mol, S.; Gilissen, R.; Motte, M.; Lançois, D.; Bolle, M.; Bonroy, K.; Lill, H., Andries, K.; Bald, D.; Koul, A. Novel antibiotics targeting respiratory ATP synthesis in gram-positive pathogenic bacteria. Antimicrob. Agents Chemother., 2012, 56, 4131-4139

[10] Yılmaz, Ö.; Şimşek Kuş, N.; Küce, P.; Coral, G.; Çelik, A.; Gültekin, M. S. Simple and convenient preparation of some bicyclic alcohols and epoxide derivatives: Promising antibiotic activities of (rac)-dimethyl 3,8dioxatricyclo[3.2.1.02,4]oct-6-ene-6,7-dicarboxylate. Med. Chem. Res., 2015, 24(6), 2709-2716 .

[11] Glassford, I.; Teijaro, C. N.; Daher, S. S.; Weil, A.; Small, M. C.; Redhu, S. K,; Colussi, D. J.; Jacobson, M. A.; Childers, W. E.; Buttaro, B.; Nicholson, A. W.; MacKerell, A. D.; Cooperman, B. S.; Andrade, R. B. Ribosome-templated azide-alkyne cycloadditions: Synthesis of potent macrolide antibiotics by in situ click chemistry. J. Am. Chem. Soc., 2016, 138, 3136-3144.

[12] Anderson, D.; Jenkinson, P. C.; Dewdney, R. S.; Francis, A. J.; Godbert, P.; Butterworth, K. R. Chromosome aberrations, mitogen induced blastogenesis and proliferative rate index in peripheral lymphocytes from 106 control individuals of the U.K. population. Mutat. Res., 1988, 204, 407-420.

[13] Scott, D.; Galloway, S.; Marshall, R.; Ishidate, M.; Brusick, D.; Ashby, J.; Myhr, B. Genotoxicity under extreme culture conditions. Mutat. Res., 1991, 257, 147-205.

[14] Çelik, A.; Akbas, E. Evolution of sister chromatid exchange and chromosomal aberration frequencies in peripheral blood lymphocytes of gasoline station attendants. Ecotoxicol. Environ. Saf. 2005, 60 106-112.

[15] Çelik, A.; Aras Ateş, N. The frequency of sister chromatid exchanges in cultured human peripheral blood lymphocyte treated with metronidazole in vitro. Drug Chem. Toxicol., 2006, 1, 85-94,

[16] Moorhead, P. S.; Novell, W. J.; Wellman, D. M.; Battips, D.; Hungerford, A. Chromosome preparations of leukocytes cultured from peripheral blood. Exp. Cell. Res., 1960, 20, 613-616. 
[17] Ozturk, F.; Acik, L.; Sener, I.; Karci, F.; Kilic, E. Antimicrobial properties and DNA interactions studies of 3hetarylazoquinoline- 2,4-diol compounds. Turk. J. Chem., 2012, 36, 293-302.

[18] Türker, B. L. DFT study of tautomerism in aklavinone. Turk. J. Chem., 2013, 37, 547-557.

[19] Naydenova, E.; Troev, K.; Topashka-Ancheva, M.; Hagele, G.; Ivanov, I.; Kril, A. Synthesis, cytotoxicity and clastogenicity of novel $\alpha$-aminophosphonic acids. Amino Acids, 2007, 33, 695-702

[20] Kishali, N. H.; Doğan, D.; Şahin, E.; Gunel, A.; Kara, Y.; Balci, M. Stereoselective Synthesis of Carbaheptopyranose Derivatives: 5a-Carba-6-deoxy- $\alpha$-DL-galacto-heptopyranose and 5a-Carba-6-deoxy- $\alpha$ DL-gulo-heptopyranose. Tetrahedron, 2011, 67, 1193-1200.

[21] Şimşek, N.; Arici, C.; McKee, M. L.; Ülkü, D.; Balci, M. High Temperature bromination XIII:1 bromination of dimethyl 7-oxabicyclo[2.2.1]hepta-2,5-diene-2,3-dicarboxylate. Struc. Chem., 2001, 12(3/4), 305-311.

[22] Bauer, A. W.; Kirby, W. M. M.; Serris, J. C.; Turck, M. Antibiotic susceptibility testing by a standardized single disc method. Am. J.Clin. Pathol., 1966, 45, 493-496.

[23] Balouri M.; Saiki M.; Ibnsouda S. K. Methods for in vitro evaluting antimicrobial activity: A review. J. Pharmaceut. Anal. 2016, 6,71-79.

[24] Brady, W. T. Synthetic applications involving halogenated ketenes, Tetrahedron, 1981, 37, $2949-2966$.

[25] Sengul, M. E.; Simsek, N.; Balci, M. An unprecedented Co(II) tetraphenylporphyrin catalyzed decomposition of bicyclic endoperoxides: A new approach to substituted furofuran systems. Eur. J. Org. Chem., 2000, 7, 1359-1363.

[26] Liotta, F. J.; Duyne, G. V.; Carpenter, B. K. Structures and rearrangement mechanisms for some bicycle[6.1.0]nona-2,4,6-triene complexes of chromium, molybdenum, and tungsten. Organometallics 1987, 6, 1010-1023.

[27] Davis, K. M.; Carpenter, B. K. Unusual facial selectivity in the cycloaddition of singlet oxygen to a simple cyclic diene (1). J. Org. Chem. 1996, 61, 4617-4622.

[28] Silva F.; Lourenço O.; Queiroz J.A. and Domingues FC. Bacteriostatic versus bactericidal activity of ciprofloxacin in Escherichia coli assessed by flow cytometry using a novel far-red dye. The J. Antibiot. 2011, 64(4),321-325.

[29] Çelik, A. The assessment of genotoxicity of carbamazepine using cytokinesis-block (CB) micronucleus assay in cultured human blood lymphocytes, Drug. Chem. Toxicol., 2006, 29, 227-236.

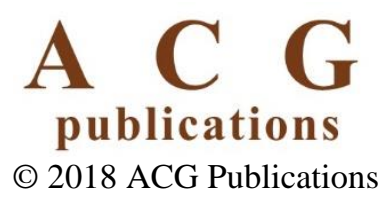

